\title{
KEDUDUKAN LEGAL OFFICER KSP. RODA SEJAHTERA DALAM MENJAMIN AKTIVITAS PERUSAHAAN SUATU KAJIAN UNDANG-UNDANG NOMOR 25 TAHUN 1992 TENTANG PERKOPERASIAN
}

\author{
Wahyu Puji Widodo \\ Mahasiswa Program Studi Magister Hukum \\ Universitas Semarang
}

\begin{abstract}
ABSTRAK
Peran dan fungsi Legal Officer dalam pengelolaan manajemen koperasi sangatlah penting dalam rangka mencapai kesejahteraan bersama secara efektif dan efisien, karena koperasi sebagai bentuk usaha bersama juga harus melakukan fungsi-fungsi manajemen. Permasalahan yang dihadapi koperasi pun beragam, baik dari masalah internal koperasi maupun masalah eksternal, selain itu masalah permodalan koperasi, dan masalah re-generasi dalam pengurusan koperasi juga merupakan kendala yang dapat menghambat pertumbuhan koperasi.

Metode penelitian yang digunakan adalah yuridis empiris, yaitu pendekatan terhadap suatu permasalahan dengan cara melihat dari segi peraturan perundang-undangan yang berlaku dan kenyataan yang terjadi

di lapangan. Penelitian ini didukung dengan pedoman wawancara dari para narasumber, dan data sekunder yang diperoleh dari buku-buku, peraturan perundang-undangan tentang Koperasi, Legal Officer, serta dokumen lainnya yang berkaitan dengan permasalahan yang diteliti.

Berdasarkan hasil penelitian dapat disimpulkan bahwa : 1) Legal Officer dibutuhkan dalam rangka mendorong peningkatan kinerja dan nilai perusahaan karena keberhasilan koperasi merupakan suatu prestasi dalam melaksanakan kegiatan berbisnis dalam meningkatkan kesejahteraan anggotanya dan masyarakat pada umumnya, 2) Berbagai permasalahan-permasalahan yang dihadapi Legal Officer KSP. Roda Sejahtera lebih banyak dari sektor penanganan kredit macet yang dapat menghambat perkembangan usaha koperasi. Dalam menangani permasalahan kredit macet ini khususnya, pihak Legal Officer melakukan pendekatan dan penetapan strategi dengan lebih mengedepankan mediasi sebagai salah satu cara penyelesaian masalahnya.
\end{abstract}

Kata kunci : Legal Officer, Koperasi, dan Manejemen. 


\begin{abstract}
The role and function of the Legal Officer in managing cooperative management is very important. It is done in order to achieve shared prosperity effectively and efficiently, because cooperatives as a form of joint venture must also carry out management functions. Problems faced by cooperatives are also diverse, both from internal cooperative problems and external problems, besides the problem of cooperative capital, and the problem of re-generation in managing cooperatives is also an obstacle that can hinder the growth of cooperatives.

The research method used was empirical juridical, namely the approach to a problem by looking at the terms of the applicable legislation and the reality that happened in the field. This research was supported by guidelines for interviews from resource persons, and secondary data obtained from books, legislation concerning Cooperatives, Legal Officers, and other documents relating to the problems under the study.

Based on the results of the study, it can be concluded that: 1) Legal Officers are needed in order to encourage increased performance and corporate value because the success of cooperatives is an achievement in carrying out business activities in improving the welfare of its members and society in general, 2) Various problems faced by Legal Officer of KSP. Roda Sejahtera is more than the non-performing loan sector that can hinder the development of cooperative business. In dealing with the problem of bad debts in particular, the Legal Officer approaches and determines the strategy by prioritizing mediation as one way to resolve the problem.
\end{abstract}

Keywords: Legal Officer, Cooperative, and Management. 
A. Pendahuluan

Secara umum yang dimaksud dengan Koperasi adalah suatu badan usaha bersama yang bergerak dalam bidang perekonomian, beranggotakan orang-orang yang umumnya berekonomi lemah yang bergabung secara sukarela dan atas dasar persamaan hak, dan kewajiban melakukan suatu usaha yang bertujuan untuk memenuhi kebutuhan-kebutuhan para anggotanya.

Di Indonesia sendiri telah diundangkan Undang-Undang Nomor 25 Tahun 1992 tentang Perkoperasian Koperasi di definisikan sebagai badan usaha yang beranggotakan orang seorang atau badan hukum koperasi dengan melandaskan kegiatannya berdasarkan prinsipprinsip koperasi sekaligus sebagai gerakan ekonomi rakyat yang berdasar atas asas kekeluargaan.

Pada abad ke-20 Koperasi tumbuh dari kalangan rakyat, ketika penderitaan dalam lapangan ekonomi dan sosial yang ditimbulkan oleh sistem kapitalisme semakin memuncak. Hal ini lantas mendorong beberapa orang mempersatukan diri untuk menolong dirinya sendiri dan manusia sesamanya yang penghidupannya sederhana dengan kemampuan ekonomi terbatas, terdorong oleh

\footnotetext{
${ }^{1}$ G. Kartasapoetra, A.G. Kartasapoetra, Bambang.S, dan A. Setiady, Koperasi Indonesia, (Jakarta : Rineka Cipta, 2007), hlm 1.
}

\section{Latar belakang}

penderitaan dan beban ekonomi yang sama. ${ }^{2}$

Terdapat kerancuan dalam

pelaksanaan manajemen

koperasi itu sendiri, banyak orang menafsirkan dan menjalankan koperasi sesuai dengan sistem perbankan karena sama-sama bergerak untuk menghimpun dana, namun demikian terdapat perbedaan prinsip bahwa sebagaimana disebutkan dalam Undang-Undang Nomor 10 Tahun 1998 tentang Perubahan atas Undang-Undang Nomor 7 Tahun 1992 tentang Perbankan, Pasal 1 angka 2 menyebutkan bahwa Bank adalah badan usaha yang menghimpun dana dari masyarakat dalam bentuk simpanan dan menyalurkannya kepada masyarakat dalam bentuk kredit dan/atau bentuk-bentuk lainnya dalam rangka meningkatkan taraf hidup rakyat banyak, sedangkan koperasi lebih mengedepankan azas kekeluargaan sebagaimana diatur dalam Undang-Undang Nomor 25 tahun 1992 tentang Perkoperasian Pasal 1 yang menyebutkan bahwa Koperasi adalah badan usaha yang beranggotakan orang-seorang atau badan hukum Koperasi dengan melandaskan kegiatannya berdasarkan prinsip Koperasi sekaligus sebagai gerakan ekonomi rakyat yang berdasar atas asas kekeluargaan.

\footnotetext{
${ }^{2}$ Malahayati, Apa itu Koperasi dan Sejarah terbentuknya Koperasi, malahayati.ac.id diakses pada 20 April 2018.
} 
Perbedaan dalam sistem pengawasan dalam pengelolaan kegiatan antara koperasi dengan perbankan juga dapat memberikan peluang keleluasaan bagi para anggota koperasi untuk bertindak sewenang-wenang dalam menjalankan kewajibannya dalam hal kepatuhan melakukan pembayaran angsuran pinjaman kredit. Tidak adanya standart operasional yang baku untuk melakukan mengecekan terlebih dahulu terhadap kridibilitas calon anggota koperasi di Bank Indonesia sebelum anggota tersebut akan mengajukan pinjaman koperasi, selain itu juga karena faktor lemahnya sistem manajemen koperasi karena adanya ketimpangan dalam hal pengambilan keputusan antara legal officer dengan pihak pengurus koperasi itu sendiri, sehingga sering kali membuka peluang untuk timbulnya kerugian perusahaan.

Legal Officer dibutuhkan oleh perusahaan dalam rangka mendorong peningkatan kinerja, keamanan, dan nilai perusahaan. Pada perusahaan yang bergerak di bidang perbankan atau lembaga pembiayaan, posisi legal officer biasanya menjadi komite kredit dengan bagian account officer dan pimpinan untuk mengkaji dan memutuskan apakah kredit yang dimohonkan nasabah akan diberikan atau tidak.

Legal Officer ini harus benar-benar orang yang memiliki loyalitas yang tinggi kepada perusahaan, karena kedudukannya yang strategis ini dapat membuat seorang legal officer memiliki hampir semua informasi tentang perusahaan, sehingga harus hati-hati dalam memilih seorang legal officer. Selain itu dengan kedudukannya yang strategis tersebut legal officer dapat menjadi pemantau yang dapat langsung mendeteksi adanya permasalahan hukum di internal maupun eksternal perusahaan.

Berkaitan dengan hal tersebut diatas, maka Penulis tertarik untuk mengkaji lebih dalam dan menyusun Jurnal mahasiswa yang berjudul :

"KEDUDUKAN LEGAL

OFFICER KSP. RODA

SEJAHTERA DALAM

MENJAMIN AKTIVITAS

PERUSAHAAN, SUATU KAJIAN

UNDANG-UNDANG NOMOR 25

TAHUN 1992 TENTANG

PERKOPERASIAN".

B. Perumusan Masalah

Perumusan masalah dalam penulisan ini adalah :

1. Bagaimana kedudukan legal officer KSP. Roda Sejahtera dalam menjamin aktivitas perusahaan sesuai dengan Undang-Undang Nomor 25 Tahun 1992 tentang Perkoperasian?

2. Bagaimana permasalahan yang dihadapi dan solusi yang diambil oleh legal officer dalam menjamin aktivitas koperasi ?

C. Metode Penelitian

1) Metode Pendekatan

Pendekatan yang penulis gunakan dalam penelitian ini adalah metode pendekatan yuridis empiris atau yuridis 
sosiologis, karena ada keterkaitan antara faktor yuridis dan faktor empiris. Adapun yang dimaksud dengan pengertian faktor yuridis adalah bahwa dalam mengadakan pendekatan, prinsip-prinsip dan peraturanperaturan yang masih berlaku dipergunakan dalam meninjau dan melihat serta menganalisa permasalahan yang menjadi objek penelitian.

2) Spesifikasi Penelitian

Spesifikasi penelitian yang dipilih dalam penelitian ini berupa penelitian diskriptif analistis, yaitu penelitian yang bermaksud untuk memberikan gambaran (deskriptif) mengenai Kedudukan Legal officer KSP. Roda Sejahtera dalam menjamin aktivitas peusahaan, suatu kajian Undang-Undang Nomor 25 Tahun 1992 tentang Perkoperasian, dan berusaha memahami secara lebih mendalam dengan kajiankajian terhadap masalah hukum dan hal-hal yang melatarbelakangi terjadinya masalah hukum tersebut.

3) Sumber dan jenis data Jenis dan sumber data yang dipergunakan dalam penelitian iniadalah :

1. Data Primer

Data primer adalah data yang diperoleh langsung dari masyarakat. Dalam penelitian lapangan, peneliti melakukan wawancara karena diharapkan dapat

memberikan keuntungan yaitu memperoleh informasi langsung.

2. Data Sekunder

Data sekunder adalah data yang diperoleh melalui studi kepustakaan. Untuk memperoleh data sekunder, peneliti mendapatkan dan mempelajari literaturliteratur peraturan perundang-undangan serta pendapat para ahli yang berhubungan dengan pokok permasalahan yang akan dipergunakan sebagai landasan pemikiran yang bersifat teoritis.

4) Teknik Pengumpulan Data

Teknik pengumpulan data adalah suatu usaha yang sadar untuk mengumpulkan data yang dilakukan secara sistematis dengan dengan suatu prosedur yang terstandart.

5) Teknik analisis Data

Metode yang digunakan adalah analisis kualitatif, yaitu data yang diperoleh melalui penelitian lapangan maupun penelitian kepustakaan kemudian disusun secara sistematif, dan selanjutnya dianalisa secara kualitatif untuk mencapai kejelasan masalah yang akan dibahas. Data tersebut kemudian dianalisa secara interpretatif menggunakan teori maupun

\footnotetext{
${ }^{3}$ I Made Pasek Diantha, Metodologi

Penelitian Hukum Normatif (Jakarta :

Prenada Media Grup, 2016), hlm. 142
} 
hukum positif yang telah dituangkan, kemudian secara deduktif ditarik kesimpulan untuk menjawab permasalahan yang ada.

\section{Tinjauan Pustaka \\ I. Koperasi}

Secara umum yang dimaksud dengan Koperasi adalah suatu badan usaha bersama yang bergerak dalam bidang perekonomian, beranggotakan mereka yang umumnya berekonomi lemah yang bergabung secara sukarela dan atas dasar persamaan hak, berkewajiban melakukan suatu usaha yang bertujuan untuk memenuhi kebutuhan-kebutuhan para anggotanya. ${ }^{5}$

Untuk

memberikan pengertian tentang apakah yang dimaksud dengan Koperasi Indonesia berdasarkan beberapa pengertian mengenai koperasi tersebut diatas, maka harus sesuai dengan :

1. Cita-cita segenap bangsa Indonesia, yaitu terbentuknya negara adil dan makmur yang menyeluruh;

2. Kondisi-kondisi yang berlaku serta kebutuhan-kebutuhan yang nyata dari masyarakat umumnya;

3. Pasal 33 ayat (1) UndangUndang Dasar 1945

\footnotetext{
${ }^{4}$ Ronny Hanitijio Soemitro, Metodologi Penelitian Hukum dan Jurimetri, (Jakarta : Ghalia Indonesia, 1995), hlm 119

${ }^{5}$ G. Kartasapoetra, Bambang S, dan A Setiady, Koperasi Indonesia, (Jakarta : Rineka Cipta, 2007), hlm 1.
}

Landasan-landasan koperasi dapat terbagi menjadi 3 (tiga) bagian, yaitu : ${ }^{6}$

1. Landasan Idiil

Bagi bangsa Indonesia, Pancasila yang menjadi falsafah negara dan bangsa telah menjadi landasan Idiil Koperasi, sebagaimana dituangkan dalam Pasal 2 Undang-Undang Nomor 25 Tahun 1992 tentang Perkoperasian. Ke-5 (kelima) sila dalam Pancasila, yaitu :

1) Ketuhanan Yang Maha Esa;

2) Kemanusian yang adil dan beradab;

3) Persatuan Indonesia;

4) Kerakyatan yang dipimpin oleh hikmat kebijaksanaan dalam permusyawaratan perwakilan;

5) Keadilan sosial bagi seluruh rakyat Indonesia.

2. Landasan Strukturil dan Landasan Gerak Landasan strukturil Koperasi Indonesia adalah Undang-Undang Dasar Tahun 1945 dan landasan geraknya adalah Pasal 1 ayat (1) UndangUndang Dasar tahun 1945 beserta penjelasannya.

Pasal 33 ayat (1) UndangUndang Dasar Tahun 1945 berbunyi :

"Perekonomian disusun sebagai usaha bersama berdasarkan atas azas-azas kekeluargaan". Dalam Pasal tersebut tercantum dasar demokrasi ekonomi bahwa produksi dikerjakan oleh semua untuk semua di bawah pimpinan atau penilikan anggota-anggota

\footnotetext{
${ }^{6}$ Ibid, hlm 6.
} 
masyarakat. Kemakmuran masyarakatlah yang diutamakan bukan kemakmuran orang perorangan. Oleh sebab itu perekonomian disusun sebagai usaha bersama berdasarkan atas azas kekeluargaan. Bangun perusahaan yang sesuai dengan falsafah tersebut adalah Koperasi.

3. Landasan Mental

Agar koperasi dapat tumbuh dan berkembang dengan baik dalam mencapai tujuannya, harus ditopang dengan kuat oleh sifat mental para anggotanya, yaitu setia kawan dan kesadaran berpribadi (solidarity and individuality). Rasa setia kawan ini sangat penting karena tanpa rasa itu maka tidaklah mungkin ada kerja sama yang baik.

Pasal 2 Undang-Undang Nomor 25 Tahun 1992 tentang Perkoperasian juga menyebutnya mengenai azas koperasi yaitu kekeluargaan.

Dengan azas kekeluargaan telah mencerminkan adanya kesadaran dari hati nurani manusia untuk mengerjakan segala sesuatu dalam koperasi oleh semua untuk semua, di bawah pimpinan pengurus serta penilikan dari para anggota atas dasar keadilan dan kebenaran serta keberanian berkorban bagi kepentingan bersama.

Prinsip koperasi diatur dalam Pasal 5 Undang-Undang Nomor 25 Tahun 1992 tentang Perkoperasian, yaitu :

1) Koperasi melaksanakan prinsip koperasi sebagai berikut : a. Keanggotaan bersifat suka rela dan terbuka;

b. Pengelolaan dilakukan secara demokratis;

c. Pembagian Sisa Hasil Usaha dilakukan secara adil sebanding dengan besarnya jasa usaha masing-masing anggota;

d. Pemberian balas jasa yang terbatas terhadap modal;

e. Kemandirian.

2) Dalam mengembangkan koperasi, maka koperasi melaksanakan pula prinsip koperasi sebagai berikut :

a. Pendidikan perkoperasian;

b. Kerja sama antar koperasi.

\section{Legal Officer}

Legal Officer merupakan salah satu profesi yang menuntut kualifikasi dari lulusan Fakultas Hukum. Mengenai harus atau tidaknya legal officer adalah advokat, hal tersebut kembali pada kebutuhan dan kebijakan perusahaan tersebut. Kamus Besar Bahasa Indonesia memberikan pengertian Profesi sebagai bidang pekerjaan yang dilandasi pendidikan keahlian (keterampilan, kejuruan dan sebagainya).

Menurut Lili Rasjidi profesi adalah pekerjaan tetap berupa pelayanan (service occupation). Pelaksanaanya dijalankan dengan menerapkan pengetahuan ilmiah dalam bidang tertentu, dihayati sebagai suatu panggilan hidup, serta terikat pada etika umum dan etika khusus (etika profesi) yang bersumber pada semangat 
pengabdian terhadap sesama manusia.

Menurut Brandeis, untuk dapat disebut sebagai profesi, maka pekerjaan itu sendiri harus mencerminkan adanya dukungan berupa : ${ }^{8}$

1. Ciri-ciri

pengetahuan

(Intellectual Character);

2. Diabadikan untuk kepentingan orang lain;

3. Keberhasilan tersebut bukan didasarkan pada keuntungan finansial;

4. Didukung oleh adanya organisasi (association) profesi dan organisasi profesi tersebut antara lain menentukan berbagai ketentuan yang merupakan kode etik, serta pula bertanggungjawab dalam memajukan dan menyebarkan profesi yang bersangkutan;

5. Ditentukan oleh adanya standar kualifikasi profesi.

Sedangkan menurut Franz Magnis Suseno profesi ini terbagi-bagi. Profesi dapat dibedakan atas profesi umum dan profesi yang luhur, Profesi umum adalah pekerjaan yang dilakukan sebagai kegiatan pokok untuk menghasilkan nafkah hidup dan yang mengandalkan suatu keahlian khusus. Persyaratan adanya keahlian yang khusus inilah yang membedakan antara pengertian profesi dan pekerjaan, walaupun sulit mencari garis pemisah yang tajam antara

\footnotetext{
${ }^{7}$ I Gede A.B. Wiranata, Dasar-Dasar Etika dan Moralitas, (Bandung : Citra Aditya Bhakti,2000,) hlm 5.

${ }^{8}$ Liliana Tedjosaputro, Etika Profesi Notaris dalam Penegakan Hukum Pidana,

(Yogyakarta:Bigraf Publishing,1995), hlm.3.
}

keduanya. Profesi yang luhur adalah profesi yang pada hakikatnya merupakan suatu pelayanan pada manusia atau masyarakat, meskipun mereka memperoleh nafkah, namun nafkah bukan tujuan utamanya. ${ }^{9}$

Posisi legal officer dalam suatu perusahaan memiliki peranan penting karena legal officer tidak hanya mengurus masalah intern perusahaan, tetapi juga mengurus masalah ekstern perusahaan. Selain itu legal officer juga berperan sebagai pengambil keputusan dalam permasahalan hukum. ${ }^{10}$

\section{Banyak}

perusahaan

menempatkan legal officer secara fungsional, yaitu kedudukan sebagai staff ahli direksi. Hal ini disebabkan karena kedudukannya berada langsung di bawah direksi, sehingga dapat dengan mudah melakukan koordinasi dengan bagian-bagian lain dalam perusahaan, seperti halnya pada bagian personalia, marketing, maupun pada bagian keuangan perusahaan. ${ }^{11}$

Tugas legal officer untuk perusahaan yang berskala besar, dapat dibagi menjadi beberapa bagian, seperti legal officer yang bertugas menangani dokumen perijinan atau legal officer yang menangani permasalah hukum,

\footnotetext{
${ }^{9}$ Shidarta, Moralitas Profesi Hukum,

(Bandung : Refika Aditama,2009), hlm 104.

10 Jimmy Joses Sembiring, Panduan Mengelola Perizinan, Dokumen, HAKI,Ketenagakerjaan, dan Masalah Hukum di Perusahaan, Cetakan Pertama, (Jakarta : Transmedia Pustaka, 2009), hlm 1.

11 Sudaryat, Legal Officer, Cetakan ke-1, (Bandung : Oase Media, 2008), hlm 11.
} 
baik untuk permasalahan perdata maupun pidana. Namun pada perusahaan menengah, legal officer menangani semua hal termasuk dokumen dan segala permasalahan macam hukum perusahaan. ${ }^{12}$ Tanggung jawab legal officer relatif mudah dipelajari, karena semua yang dikerjakan berdasar pada logika hukum, yang pasti dimiliki hampir semua Sarjana Hukum. Pada dasarnya legal officer berperan sebagai "Team Support" untuk mencapai suatu tujuan perusahaan.

\section{Hasil dan Pembahasan \\ 1. Kedudukan Legal Officer KSP. Roda Sejahtera dalam menjamin aktivitas perusahaan sesuai dengan Undang-Undang Nomor 25 Tahun 1992 tentang Perkoperasian}

Keberhasilan koperasi merupakan suatu prestasi dalam melaksanakan kegiatan berbisnis dalam meningkatkan kesejahteraan anggotanya dan masyarakat pada umumnya. ${ }^{13}$ Pendapat lain dikemukakan oleh Alfred Hanel bahwa keberhasilan suatu koperasi dalam menjalankan misinya akan tergantung pada partisipasi anggota di dalam kedudukannya sebagai

\footnotetext{
12 Jimmy Joses Sembiring, Op. Cit.

${ }^{13}$ Any Meilani dan Sri Ismulyaty, Hubungan antara Faktor Anggota dan Partisipasi terhadap Keberhasilan Usaha Koperasi, (Jakarta : Lembaga Penelitian Universitas Terbuka, 2002), hlm 13.
}

pemilik (owner) dan pelanggan (customers). ${ }^{14}$ Undang-Undang Nomor 25 Tahun 1992 tentang Perkoperasian pasal 43 ayat (1) menyatakan bahwa usaha koperasi adalah usaha yang berkaitan dengan kepentingan untuk meningkatkan usaha dan kesejahteraan anggota. Usaha koperasi terutama diarahkan pada bidang usaha yang berkaitan langsung dengan kepentingan anggota, baik untuk menunjang usaha maupun kesejahteraanya. Pengelolaan usaha koperasi harus dilakukan secara produktif, efektif dan efisien dalam arti ; koperasi harus mempunyai kemampuan mewujudkan pelayanan usaha yang dapat meningkatkan nilai tambah dan manfaat yang sebesarbesarnya pada anggota dengan tetap mempertimbangkan untuk memperoleh sisa hasil usaha yang wajar. Hal yang terpenting adalah keberhasilan organisasi dari tinjauan efektivitas organisasi harus dilihat dari segi produktivitas, moral dan kepuasan anggota. ${ }^{15}$ Koperasi Roda Sejahtera merupakan salah satu bentuk koperasi simpan pinjam berkedudukan di Kota

\footnotetext{
${ }^{14}$ Ramudi Arifin, Sisa Hasil Usaha, (Jakarta : Seminar Pengkajian Perkoperasian Institut Manajemen Koperasi Indonesa, 2002), hlm 66.

${ }^{15}$ Ibid
} 
Semarang yang didirikan berdasarkan rapat pembentukan koperasi yang diselenggarakan oleh para anggotanya pada tanggal 28 Juni 2000 dan telah mendapatkan pengesahan dari Kantor Menteri Negara Koperasi dan Pengusaha Kecil dan Menengah Republik Indonesia Kantor Departemen Koperasi Pengusaha Kecil dan Menengah Kota Semarang yang didaftarkan dalam Daftar Umum pada tanggal 27 September 2000 Nomor : 0428/BH/KDK.11-30/IX/2000, yang telah mengalami beberapa kali perubahan, terakhir berdasarkan Akta Pernyataan Keputusan Rapat Anggota Perubahan Anggaran Dasar Nomor 17 tanggal 22 Nopember 2013 yang dibuat dihadapan ZULAICHA, Sarjana Hukum, Magister Kenotariatan, Notaris Kota Semarang dan berdasarkan Keputusan Gubenur Jawa Tengah Nomor : 01/PAD/XIV/I/2014 tertanggal 08 Januari 2014.

Kegiatan Usaha
Koperasi Simpan Pinjam diatur dalam Pasal 19 Peraturan Pemerintah Nomor 9 Tahun 1995. Kegiatan usaha Koperasi Simpan Pinjam meliputi :

1) menghimpun simpanan koperasi berjangka dan tabungan koperasi dari anggota dan calon anggotanya, koperasi lain dan atau anggotanya;
2) memberikan pinjaman kepada anggota, calon anggotanya, koperasi lain dan atau anggotanya.

Kedudukan legal officer di KSP. Roda Sejahtera berada langsung dibawah pengurus, dan berwenang penuh terhadap bagian-bagian lain dibawahnya.Dalam menjamin aktivitas perusahaan sesuai dengan Undang-Undang Nomor 25 Tahun 1992 tentang Perkoperasian, tugas dan tanggung jawab legal officer di KSP. Roda Sejahtera meliputi :

1. Dalam pemberian kredit Sebelum dilakukannya pencairan kredit kepada nasabah, seorang legal officer bertanggung jawab penuh, baik terhadap keabsahan jaminan yang akan diagunkan, maupun mengenai kredibilitas calon debitur tersebut. Untuk mencegah terjadinya kredit bermasalah di kemudian hari, penilaian seorang legal officer dalam memberikan persetujuan terhadap suatu permohonan pencairan kredit dilakukan dengan berpedoman terhadap beberapa hal sebagai berikut :
a) Personality;
b) Purpose
c) Prospect
d) Payment

2. Dalam kaitan dengan perjanjian 
Sebelum dilakukannya pencairan kredit kepada nasabah, seorang legal officer juga perlu meneliti lebih mendalam mengenai klausal-klausal yang diatur dalam perjanjian, sebagai dasar pengikatan keduabelah pihak. Perjanjian adalah suatu peristiwa ketika satu orang atau lebih berjanji atau saling berjanji untuk melakukan perbuatan hukum tertentu. Meskipun dimungkinkan adanya perjanjian lisan, namun sebaiknya suatu perjanjian berbentuk tertulis. Hal ini erat kaitannya dengan sistem pembuktian perdata di Indonesia yang lebih mengutamakan kebenaran formal. Jika terjadi sengketa di kemudian hari berkenaan dengan perjanjian itu sendiri, para pihak dapat mengajukan perjanjian tersebut sebagai salah satu bukti. ${ }^{16}$

3. Kaitan dengan Notaris

Legal Office berwenang untuk memilih dan/atau menentukan Notaris sebagai pejabat umum yang mengesahkan suatu perjanjian/perikatan dalam perjanjian kredit yang akan dilakukan. Menentukan rekanan Notaris yang berkualitas berpengaruh juga terhadap keamanan objek jaminan, karena

\footnotetext{
${ }^{16}$ Sudaryat, Legal Officer, (Bandung : Oase Media, 2008), hlm 34.
}

kepastian waktu penyelesaian proses objek jaminan dapat mengurangi resiko permasalahan hukum dikemudian hari.

4. Penyelesaian Kredit Macet.

Tindakan lembaga

koperasi dalam usaha menyelamatkan dan menyelesaikan kredit macet beranekaragam, tergantung pada kondisi kredit macet tersebut.

Dalam penyelesain kredit macet, legal officer KSP Roda Sejahtera akan menganalisa terlebih dahulu mengenai permasalahan yang terjadi, dengan cara memilah-milah permasalahan antara debitur satu dengan yang lainnya, sehingga dapat ditemukan jalan keluar yang terbaik untuk keduabelah pihak.

5. Pengawasan Sumber Daya Manusia (SDM)

Selain beberapa hal tersebut diatas yang berkaitan dengan kredit, legal officer juga bertanggung jawab dan berwenang dalam pengaturan sumber daya manusia di dalam organ koperasi itu sendiri, seperti beberapa hal sebagai berikut :

1) Perekrutan dan/atau pemberhentian karyawan;

2) Kontrak kerja karyawan; 
3) Pemberian uang pesangon;

4) Pengurusan BPJS ketenagakerjaan baik bagi pengurus maupun bagi karyawan koperasil

6. Kesehatan Koperasi.

Tingkat kesehatan tidak hanya dinilai dari aspek laporan keuangannya saja, tetapi juga dilihat dari aspek pelengkap dalam koperasi simpan pinjam tersebut, sebagai salah satu contoh adalah ada tidaknya visi dan misi tertulis dalam koperasi simpan pinjam tersebut.

2. Permasalahan-permasalahan yang dihadapi oleh Legal Officer dalam menjamin aktivitas koperasi serta tata cara penyelesainnya.

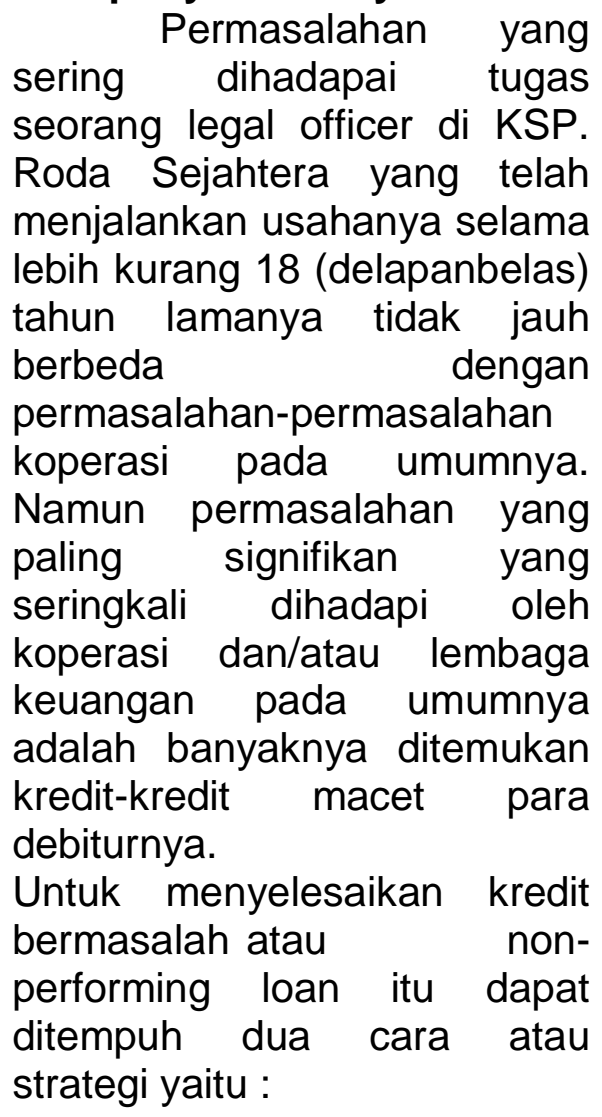

1. Penyelamatan kredit.

Langkah upaya dalam penyelamatan kredit macet di KSP. Roda Sejahtera menerapkan beberapa langkah sebagai berikut:
1) Melalui rescheduling (penjadwalan kembali)
2) Melalui reconditioning (persyaratan kembali)
3) Melalui restructuring (penataan kembali)

2. Penyelesaian Kredit

1) Penyelesaian kredit bermasalah secara damai.

Penyelesaian kredit bermasalah secara damai dapat dilakukan terhadap debitur yang beritikad baik untuk menyelesaikan

kewajibannya dan cara yang ditempuh dalam penyelesaian ini dianggap lebih baik dibandingkan alternatif penyelesaian melalui saluran hukum.

2) Penyelesaian kredit bermasalah melalui jalur hukum

Penyelesaian kredit bermasalah melalui saluran hukum ini apabila upaya restrukturisasi/

penyelesaian secara damai sudah diupayakan secara maksimal dan belum memberikan hasil atau debitur tidak menunjukkan itikad baik (onwill) dalam menyelesaikan 


\section{kewajibannya, maka penyelesaian dapat ditempuh melalui saluran hukum yakni Badan Urusan Piutang Lelang Negara (BUPLN) atau Panitia Urusan Piutang Negara (PUPN) D. Penutup atau Pengadilan Negeri.}

\section{a. Kesimpulan}

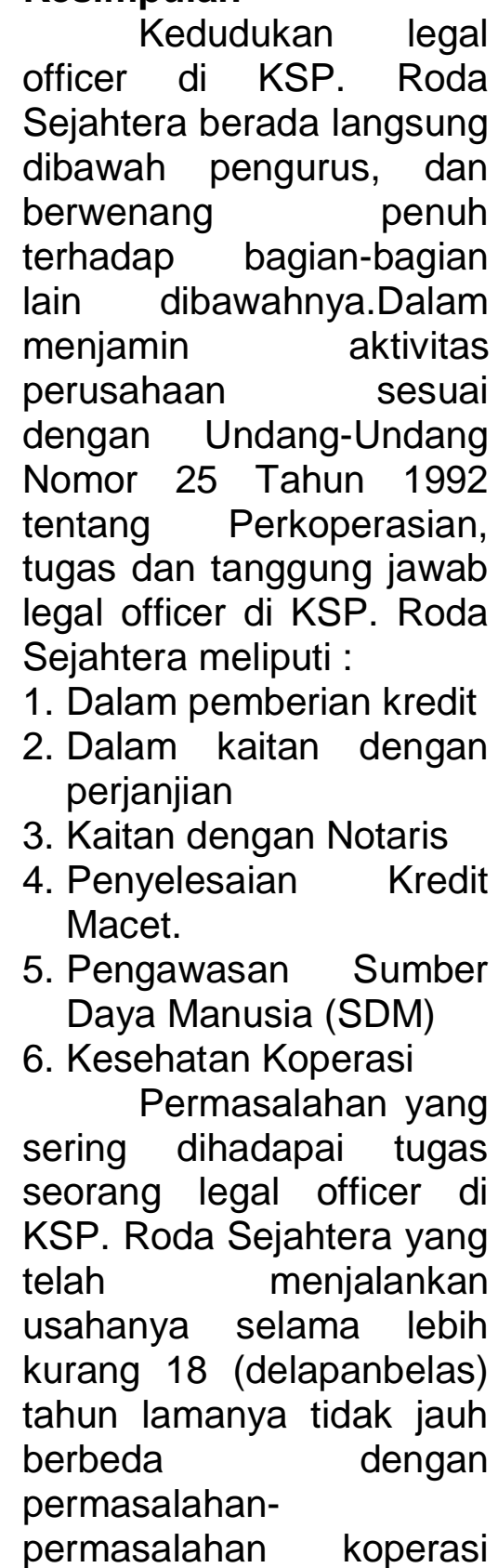

pada umumnya. Namun permasalahan yang paling signifikan yang seringkali dihadapi oleh koperasi dan/atau lembaga keuangan pada umumnya adalah banyaknya ditemukan kredit-kredit macet para debiturnya.

Untuk menyelesaikan kredit bermasalah atau non-performing loan itu dapat ditempuh dua cara atau strategi yaitu :

1. Penyelamatan kredit. Langkah upaya dalam penyelamatan kredit macet di KSP. Roda Sejahtera menerapkan beberapa langkah sebagai berikut:

1) rescheduling (penjadwalan kembali)

2) reconditioning (persyaratan kembali)

3) restructuring (penataan kembali)

2. Penyelesaian Kredit
1) Penyelesaian kredit bermasalah secara damai.
2) Penyelesaian kredit bermasalah melalui jalur hukum

\section{b. Saran}

1. Perlu ada pengawasan dan pembinaan yang lebih dari pemerintah khususnya yang dilakukan oleh Dinas Koperasi dalam mengayomi koperasikoperasi di Indonesia 
sehingga satu per satu dapat terawasi dengan baik dan kesejahteraan anggota dapat terwujud dan tercapai dengan baik.

2. Perlu ada pemahaman lebih baik dari masyarakat mengenai kedudukan koperasi yang juga merupakan badan usaha di bidang perekonomian yang bertujuan untuk meningkatkan

kesejahteraan anggota pada khususnya.

3. Dalam menjalankan usaha, koperasi perlu untuk meningkatkan pegawasan dan pengendalian yang terstruktur dan terprogram sehingga dapat mengurangi dan/atau meminimalisir adanya permasalahan yang dapat menimbulkan kerugian koperasi dalam menjalankan usahanya dan terwujudnya pengelolaan Koperasi Simpan Pinjam yang sehat dan sesuai dengan ketentuan peraturan perundangundangan yang berlaku.

\section{DAFTAR PUSTAKA}

\section{a. Buku-buku}

Any Meilani dan Sri Ismulyaty, Hubungan antara Faktor Anggota dan Partisipasi Terhadap Keberhasilan Usaha Koperasi, 2002,
Lembaga

Penelitian

Universitas

Terbuka,

Jakarta.

G. Kartasapoetra, A.G. Kartasapoetra,Bambang.S, dan A. Setiady, 2007, Koperasi Indonesia, Rineka Cipta, Jakarta.

I Made Pasek Diantha, Metodologi Penelitian Hukum Normatif , 2016, Prenada Media Grup, Jakarta

Jimmy Joses Sembiring, Panduan Mengelola Perizinan, Dokumen HAKI, Ketenagakerjaan, dan Masalah Hukum di Perusahaan, Cetakan Pertama, 2009, Transmedia Pustaka, Jakarta.

Ronny Hanitijio Soemitro, 1995, Metodologi Penelitian Hukum, Ghalia Indonesia, Jakarta.

Sudaryat, Legal Officer, Cetakan ke-1, 2008, Oase Media, Bandung.

b. Paraturan undangan

Undang-Undang dasar 1945

Kitab Undang-Undang Hukum Perdata

Undang-Undang Nomor 25 Tahun 1992 tentang Perkoperasian

Undang-Undang Nomor 10 Tahun 1998 tentang Perubahan atas

Undang-Undang Nomor 7 Tahun 1992 tentang Perbankan 
Undang-Undang Nomor 18 Tahun 2003 tentang Advokat Undang-Undang Nomor 5 Tahun 1999 tentang Larangan Praktik Monopoli dan Persaingan Usaha c. Website Tidak Sehat.

Malahayati, Apa itu Koperasi dan Sejarah terbentuknya Koperasi, malahayati.ac.id diakses pada 20 April 2018. 